\title{
PENERAPAN MULTIMETODE BERBASIS MATRIKS PADA SELEKSI PENERIMAAN CALON ASISTEN LABOR
}

\author{
Rahimullaily ${ }^{1)}$, Lakry Maltaf ${ }^{2}$ \\ 1), 2)Program Studi Sistem Informasi STMIK Indonesia Padang \\ 1)email: rahimullaily@stmikindonesia.ac.id \\ ${ }^{2)}$ email: lakrymaltaf@stmikindonesia.ac.id
}

\begin{abstract}
The survey was conducted in the Computer Laboratory of Information System of STMIK Indonesia of Padang. The Head of Laboratory determined some criteria in selecting of acceptance of labor assistant candidate. These criteria were the Candidate Application Form $(F P C)$, the Compative Achievement Index (GPA), the test score, the English test score, and the interview results. The head of the laboratory performed the process of calculating the criteria value by summing the value of each criteria to deciding who was accepted as a labor assistant. Who having the highest number of criteria, then he / she was selected as a laboratory assistant. This allows to occur the less ideal decision because the basis of decision-making based on calculations not using special calculation method yet to decision making. Therefore, the researcher performed the process of calculating of the criteria value by using matrix based calculation method that were Simple Additive Weighting (SAW) method and Analytic Hierarchy Process (AHP) method. The results of this study are expected to assist the Head of Labor in deciding the laboratory assistant based on the standard calculation as decision making.
\end{abstract}

Keyword: SAW, AHP, Labor Assistant Candidate

\section{PENDAHULUAN}

Dalam penelitian ini asisten labor merupakan orang yang bertugas dalam membantu pelaksanaan praktikum komputer di laboratorium komputer Program Studi Sistem Informasi STMIK Indonesia Padang. Kualifikasi asisten labor telah ditetapkan di STMIK Indonesia Padang sebagai berikut:

1) Minimal sudah menempuh empat semester.

2) Memiliki kemampuan salah satu dalam bahasa pemrograman.

3) Jujur dan disiplin.

Kualifikasi merupakan persyaratan minimal dimiliki oleh calon asisten labor. Beberapa kriteria dalam penseleksian penerimaan calon asisten labor. Kriteria tersebut adalah Formulir Pengajuan Calon (FPC), Indeks Prestasi Komulatif (IPK), nilai tes praktikum, nilai tes Bahasa Inggris, dan hasil interview. Rekapan nilai semua kriteria calon asisten labor diperoleh saat peneliti melakukan survei ditunjukkan pada Tabel 1. Nilai FPC $=1$ berarti lengkap, dan nilai $\mathrm{FPC}=0$ berarti tidak lengkap.

Tabel 1. Rekap Nilai Semua Kriteria Calon Asisten

\begin{tabular}{|c|c|c|c|c|c|}
\hline & FPC & IPK & $\begin{array}{l}\text { Nilai Tes } \\
\text { Praktikum }\end{array}$ & $\begin{array}{l}\text { Nilai } \\
\text { Tes B. } \\
\text { Inggris }\end{array}$ & $\begin{array}{l}\text { Hasil } \\
\text { Inter } \\
\text { View }\end{array}$ \\
\hline Feri & 1 & 3,20 & 80 & 80 & 80 \\
\hline Dion & 1 & 2,60 & 70 & 81 & 95 \\
\hline Ardi & 0 & 3,65 & 62 & 80 & 52 \\
\hline Rian & 1 & 3,01 & 81 & 50 & 54 \\
\hline Rahmad & 0 & 2,75 & 56 & 82 & 90 \\
\hline
\end{tabular}

Kepala Laboratorium melakukan proses \begin{tabular}{rrrr} 
perhitungan nilai kriteria dengan & cara \\
\hline
\end{tabular} 
Penerapan Multimetode Berbasis Matriks Pada Seleksi Penerimaan Calon Asisten

Labor

Rahimullaily, Lakry Maltaf

menjumlahkan nilai setiap kriteria untuk

Suatu matriks $\mathrm{A}_{\mathrm{m} \times \mathrm{n}}$ merupakan kumpulan

memutuskan siapa yang diterima sebagai

asisten labor. Tabel 2 menunjukkan total nilai kriteria dari calon asisten labor.

Tabel 2. Total Nilai Kriteria Calon Asisten Labor

\begin{tabular}{|l|r|}
\hline & \multicolumn{1}{|l|}{$\begin{array}{l}\text { Total Nilai } \\
\text { Kriteria }\end{array}$} \\
\hline Feri & 244,20 \\
\hline Dion & 249,60 \\
\hline Ardi & 197,65 \\
\hline Rian & 189,01 \\
\hline Rahmad & 230,75 \\
\hline $\begin{array}{l}\text { Sumber: } \quad \text { Dokumen } \\
\text { Program Studi Sistem Informasi STMIK } \\
\text { Indonesia, 2016. }\end{array}$
\end{tabular}

Berdasarkan Tabel 2 maka diperoleh bahwa Dion yang terpilih sebagai asisten labor. Hasil keputusan ini memungkinkan kurang ideal karena dasar pengambilan keputusan berdasarkan perhitungan yang belum menggunakan suatu metode perhitungan khusus pengambilan keputusan.

Oleh karena itu, peneliti melakukan proses perhitungan kriteria tersebut dengan menggunakan metode perhitungan khusus dalam pengambilan keputusan untuk menentukan asisten labor. Hal ini diharapkan dapat membantu Kepala Laboratorium yaitu adanya dasar yang kuat dalam pengambilan keputusan untuk menentukan asisten labor.

Metode perhitungan kriteria dalam penelitian ini yaitu perhitungan kriteria dengan dua metode yang berbasis matriks. Kedua metode tersebut adalah metode Simple Additive Weighting (SAW) dan metode Analytic Hierarchy Process (AHP). bilangan, simbol atau ekspresi yang disusun berdasarkan $\mathrm{m}$ baris dan $\mathrm{n}$ kolom. Bilanganbilangan yang terdapat pada suatu matriks disebut dengan entri dari matriks. (Bill Jacob, 1990: 24). Dengan menggunakan representasi matriks, perhitungan dapat dilakukan dengan lebih terstruktur.

Bentuk umum matriks yaitu:

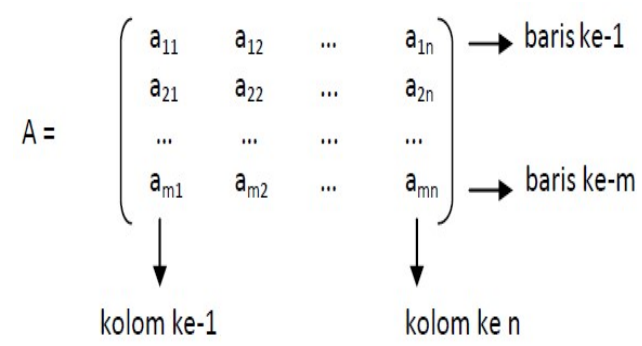

Misal terdapat suatu matriks $A_{m \times n}$ dan matriks $B_{n \times p}$. Dengan kata lain banyak kolom A sama dengan banyak baris B. Sehingga dapat didefinisikan matriks A dikali matriks B sebagai berikut:

$$
A B(i, k)=\sum_{j=1}^{n} A(i, j) B(j, k)
$$

Selanjutnya diperoleh matriks $\mathrm{AB}_{\mathrm{m} \times \mathrm{p} .}$ (Bill Jacob, 1990:26)

Menurut Dicky Nofriansah (2014:11) bahwa konsep dasar metode SAW adalah mencari penjumlahan terbobot dari rating kinerja pada setiap alternatif pada semua atribut. Dalam penelitian ini atribut merupakan kriteria dalam penseleksian penerimaan calon asisten labor. Metode ini disarankan untuk menyelesaikan permasalahan dalam pengambilan keputusan multi proses. Metode SAW membutuhkan 
proses normalisasi matriks keputusan (X) ke suatu skala yang didapat di perbandingkan dengan semua rating alternatif yang ada. Berikut rumus untuk melakukan normalisasi matriks keputusan (X) ke suatu skala yang didapat di perbandingkan dengan semua rating alternatif yang ada:

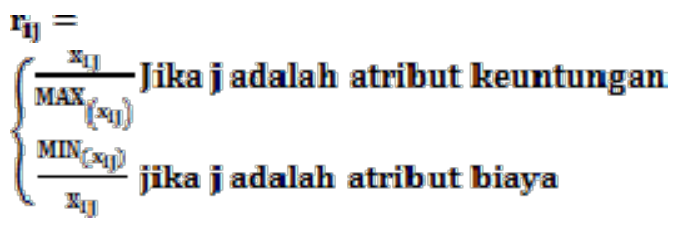

Keterangan:

$r_{i j}$ adalah rating kinerja ternormalisasi dari alternative $A_{i}$ pada atribut $\mathrm{C}_{\mathrm{j}}$;

$\mathrm{i}=1,2, \ldots, \mathrm{m}$ dan $\mathrm{j}=1,2, \ldots, \mathrm{n}$.

$r_{i j} \quad$ : rating kinerja ternormalisasi.

$\operatorname{Max}_{(x i j)} \quad$ : nilai maksimum dari setiap baris dan kolom.

$\operatorname{Min}_{(x i j)} \quad$ : nilai minimum dari setiap baris dan kolom.

$x_{i j} \quad$ : nilai atribut yang dimiliki dari setiap kriteria.

Menurut Dicky Nofriansyah (2014:12) bahwa rumus perangkingan adalah sebagai berikut:

$$
V_{i}=\sum_{j=1}^{n} \boldsymbol{r}_{i j} \boldsymbol{w}_{j 1}
$$

Nilai Preferensi untuk setiap alternatif $\left(V_{i}\right)$ diberikan rumus dan berikut keterangan dari rumus di atas:

$V_{i}$ : Nilai akhir dari alternatif

$w_{j 1}$ : bobot yang telah ditentukan $r_{i j}$ : normalisasi matriks Nilai V1 yang lebih besar mengindikasikan bahwa alternative $A_{i}$ lebih terpilih.

Langkah metode SAW adalah sebagai berikut:

a. Menentukan matriks nilai bobot pada setiap kriteria (W)

b. Menentukan matriks keputusan X.

c. Melakukan normalisasi/merubah matriks $\mathrm{X}$ ke R.

d. Menentukan nilai preferensi untuk setiap alternatif $\left(V_{i}\right)$ dengan cara menjumlahkan hasil kali antara matiks ternormalisasi $(R)$ dengan nilai bobot $(W)$. Nilai $V_{i}$ yang lebih besar mengindikasikan bahwa alternatif $A_{i}$ lebih terpilih

e. Menentukan perangkingan. Hasil akhir diperoleh dari proses perangkingan yaitu proses penjumlahan dari perkalian matriks $\mathrm{R}$ dengan $W$ sehingga diperoleh nilai terbesar yang dipilih sebagai alternative terbaik sebagai solusi. Batas rank rata-rata yang digunakan dalam penelitian ini untuk penentuan diterimanya calon asisten labor sebagai asisten labor di Laboratorium Komputer Program Studi Sistem Informasi STMIK Indonesia Padang adalah sebagai berikut:

1. $\mathrm{V}_{\mathrm{i}}>13$ maka diterima

2. $11<\mathrm{V}_{\mathrm{i}} \leq 13$ maka dapat dipertimbangkan

3. $\mathrm{V}_{\mathrm{i}} \leq 11$ maka tidak diterima 
Penerapan Multimetode Berbasis Matriks Pada Seleksi Penerimaan Calon Asisten

Labor

Rahimullaily, Lakry Maltaf

Analytic Hierarchy Process (AHP)

merupakan suatu teori umum pengukuran yang digunakan untuk menemukan skala rasio, baik dari perbandingan berpasangan yang diskrit maupun kontinu. AHP menguraikan masalah multi faktor atau multi kriteria yang kompleks menjadi suatu hirarki. Hirarki didefinisikan sebagai suatu representasi dari sebuah permasalahan yang kompleks dalam suatu struktur multi level dimana level pertama adalah tujuan, yang diikuti level faktor, kriteria, sub kriteria, dan seterusnya ke bawah hingga level terakhir dari alternatif. Dengan hirarki, suatu masalah yang kompleks dapat diuraikan ke dalam kelompok-kelompoknya yang kemudian diatur menjadi suatu bentuk hirarki sehingga permasalahan akan tampak lebih terstruktur dan sistematis (Eko Darmanto et al., 2014).

Langkah-langkah atau prosedur atau tahapan AHP meliputi:

1. Mendefinisikan masalah dan menentukan solusi yang diinginkan.

2. Menyusun hierarki dari pemasalahan yang dihadapi.

3. Membuat matriks perbandingan berpasangan (matriks persegi) yang menggambarkan kontribusi relatif atau pengaruh setiap elemen terhadap tujuan atau kriteria yang setingkat di atasnya. Perbandingan dilakukan berdasarkan pilihan dari pembuat keputusan dengan menilai tingkat kepentingan suatu elemen dibandingkan elemen lainnya. Tingkat kepentingan pada matriks perbandingan

berpasangan ditunjukkan pada Tabel 3 .

Tabel 3. Tingkat Kepentingan pada Matriks Perbandingan

Berpasangan

\begin{tabular}{|c|l|}
\hline $\begin{array}{c}\text { Intensitas } \\
\text { Kepentingan }\end{array}$ & \multicolumn{1}{|c|}{ Keterangan } \\
\hline 1 & $\begin{array}{l}\text { Kedua elemen sama } \\
\text { pentingnya }\end{array}$ \\
\hline 3 & $\begin{array}{l}\text { Elemen yang satu sedikit } \\
\text { lebih penting dari elemen } \\
\text { yang lainnya }\end{array}$ \\
\hline 5 & $\begin{array}{l}\text { Elemen yang satu lebih } \\
\text { penting dari elemen lainnya }\end{array}$ \\
\hline 7 & $\begin{array}{l}\text { Satu elemen jelas lebih } \\
\text { mutlak penting dari elemen } \\
\text { lainnya }\end{array}$ \\
\hline 9 & $\begin{array}{l}\text { Satu elemen mutlak penting } \\
\text { dari elemen lainnya }\end{array}$ \\
\hline Kebalikan & $\begin{array}{l}\text { Nilai-nilai antara dua nilai } \\
\text { pertimbangan yang } \\
\text { berdekatan }\end{array}$ \\
$\begin{array}{l}\text { Jika aktivitas i mendapat } \\
\text { satu angka dibandingkan } \\
\text { dengan aktivitas j, maka j } \\
\text { memiliki nilai } \\
\text { kebalikannya dibandingkan } \\
\text { dengan i. }\end{array}$ \\
\hline
\end{tabular}

Sumber: Kusrini (2007:134)

4. Menormalkan data, yaitu dengan membagi nilai setiap elemen di dalam matriks perbandingan berpasangan dengan nilai total dari setiap kolom.

5. Menghitung nilai eigen vektor $(\lambda)$ dari setiap elemen dan menguji konsistensinya, jika tidak konsisten maka pengambilan data perlu diulang. Nilai eigen vektor yang dimaksud adalah nilai eigen vektor yang maksimum ( $\left.\lambda_{\text {maksimum }}\right)$ diperoleh. Nilai $\lambda$ dihasilkan dari ratarata nilai bobot relative untuk tiap baris. Perhitungan bobot relative dengan cara membagi nilai setiap elemen pada matriks perbandingan berpasangan 
dengan nilai total dari setiap kolom. Selanjutnya $\lambda_{\text {maksimum }}$ didapat dengan menjumlahkan hasil perkalian jumlah kolom dengan perhitungan $\lambda$.

6. Mengulangi langkah $\mathrm{c}, \mathrm{d}$, e untuk setiap tingkat hierarki.

7. Menghitung $\lambda$ dari seluruh matriks perbandingan berpasangan. Nilai $\lambda$ merupakan bobot setiap elemen.

8. Menguji konsistensi hierarki dengan menghitung Consistency Index (CI) dan menghitung Consistency Ratio (CR). Rumus CI sebagai berikut:

$$
C I=\frac{\lambda_{\text {maksimum }}-n}{n-1}
$$

dimana $\mathrm{n}=$ banyaknya elemen.

Rumus CR sebagai berikut:

$$
C R=\frac{C I}{I R}
$$

dimana IR adalah Indeks Randon Konsisten. Daftar IR dapat dilihat pada Tabel 4.

Tabel 4. Daftar Indeks Random

\begin{tabular}{|c|c|} 
Konsisten (IR) \\
\hline Ukuran Matriks & Nilai IR \\
\hline 1 & 0 \\
\hline 2 & 0 \\
\hline 3 & 0,58 \\
\hline 4 & 0,90 \\
\hline 5 & 1,12 \\
\hline 6 & 1,24 \\
\hline 7 & 1,32 \\
\hline 8 & 1,41 \\
\hline 9 & 1,45 \\
\hline 10 & 1,49 \\
\hline 11 & 1,51 \\
\hline 12 & 1,48 \\
\hline 13 & 1,56 \\
\hline 14 & 1,57 \\
\hline 15 & 1,59 \\
\hline
\end{tabular}

Sumber: Kusrini (2007:136)
Jika tidak memenuhi dengan $\mathrm{CR}<0,1$ maka penilaian data harus diperbaiki (Eko Darmanto et al., 2014).

Perhitungan pada penelitian ini diharapkan membantu memberikan dasar kepada Kepala Labor untuk pengambilan keputusan, akan tetapi pemilihan keputusan menentukan asisten labor dikembalikan sepenuhnya kepada Kepala Laboratorium Komputer Program Studi Sistem Informasi STMIK Indonesia Padang.

\section{METODE PENELITIAN}

Urutan pelaksanaan penelitian dilakukan dengan tahapan berikut ini:

1) Melakukan survei ke Laboratorium Komputer Program Studi Sistem Informasi STMIK Indonesia Padang pada November 2016. Terdapat 5 calon asisten labor yang akan diseleksi menjadi asisten labor. Mereka adalah Feri, Dion, Ardi, Rian, dan Rahmad.

2) Melakukan pengumpulan data dengan cara melakukan wawancara dengan Kepala Laboratorium Komputer Program Studi Sistem Informasi STMIK Indonesia Padang dan memperoleh data-data calon asisten labor (ditunjukkan pada Tabel 1).

3) Merumuskan permasalahan yaitu bagaimana memproses perhitungan dengan banyak kriteria seleksi penerimaan calon asisten labor menggunakan metode Simple Additive Weighting (SAW) dan Analytic Hierarchy Process (AHP) berdasarkan 
Penerapan Multimetode Berbasis Matriks Pada Seleksi Penerimaan Calon Asisten

Labor

Rahimullaily, Lakry Maltaf

Tabel 1, sebagai dasar dalam

pengambilan keputusan dan bagaimana

hasil keputusan untuk memilih dari 5

calon asisten labor tersebut menjadi asisten labor di Laboratorium

Komputer Program Studi Sistem

Informasi STMIK Indonesia Padang.

4) Membaca dan mempelajari buku-buku atau artikel yang berhubungan dengan masalah yang dibahas

5) Melakukan penerapan perhitungan kriteria dengan metode SAW.

6) Melakukan penerapan perhitungan kriteria dengan metode AHP.

\subsection{Metode Simple Additive Weighting} (SAW)

1. Variabel kriteria yang digunakan dalam perhitungan

Kriteria preferensi merupakan persyaratan yang dibutuhkan untuk pengambilan keputusan. Berikut interval nilai preferensi yang telah dikonversikan dengan bilangan fuzzy Multiple Attribute Decision Making (FMADAM).
a) Sangat rendah $(\mathrm{SR})=1$
b) Rendah $(\mathrm{R})=2$
c) $\operatorname{Cukup}(\mathrm{C})=3$
d) $\operatorname{Baik}(B)=4$
e) Sangan baik $(\mathrm{SB})=5$

Kriteria seleksi penerimaan calon asisten labor adalah sebagai berikut: FPC $\left(\mathrm{C}_{1}\right)$, IPK $\left(\mathrm{C}_{2}\right)$, nilai tes Praktikum $\left(\mathrm{C}_{3}\right)$, nilai tes Bahasa Inggris $\left(\mathrm{C}_{4}\right)$, dan hasil interview $\left(\mathrm{C}_{5}\right)$.
2. Parameter yang digunakan dalam perhitungan

Dari $\mathrm{C}_{1}$ sampai dengan $\mathrm{C}_{5}$ maka dibuat tingkat kepentingan kriteria berdasarkan nilai bobot yang telah ditentukan ke dalam bilangan FMADAM. Rating kecocokan setiap alternative kriteria sebagai berikut:

a) Parameter FPC, ditunjukkan pada Tabel 5.

Tabel 5. Parameter FPC

\begin{tabular}{|l|c|}
\hline \multicolumn{1}{|c|}{ FPC } & Nilai \\
\hline Tidak Lengkap & 1 \\
\hline Lengkap & 5 \\
\hline
\end{tabular}

b) Parameter IPK, ditunjukkan pada Tabel 6.

Tabel 6. Parameter IPK

\begin{tabular}{|l|c|}
\hline \multicolumn{1}{|c|}{ IPK } & Nilai \\
\hline Memuaskan $(<2,00-2,75)$ & 2 \\
\hline Sangat Memuaskan $(2,76-3,50)$ & 4 \\
\hline Dengan Pujian(3,51 - 4.00) & 5 \\
\hline
\end{tabular}

c) Parameter tes praktikum, ditunjukkan pada Tabel 7.

Tabel 7. Parameter Nilai Tes Praktikum

\begin{tabular}{|l|c|}
\hline \multicolumn{1}{|c|}{ Nilai Tes Praktikum } & Nilai \\
\hline Gagal $(<55)$ & 1 \\
\hline Cukup (56-64) & 3 \\
\hline Memuaskan (65-79) & 4 \\
\hline Sangat Memuaskan (80-100) & 5 \\
\hline
\end{tabular}

d) Parameter nilai tes Bahasa Inggris, ditunjukkan pada Tabel 8 .

Tabel 8. Parameter Nilai Tes Bahasa Inggris

\begin{tabular}{|l|c|}
\hline Nilai Tes Bahasa Inggris & Nilai \\
\hline Gagal $(<55)$ & 1 \\
\hline Cukup $(55-64)$ & 3 \\
\hline
\end{tabular}




\begin{tabular}{|l|c|}
\hline Nilai Tes Bahasa Inggris & Nilai \\
\hline Memuaskan (65-79) & 4 \\
\hline Sangat memuaskan(80-100) & 5 \\
\hline
\end{tabular}

e) Parameter hasil interview, ditunjukkan pada Tabel 9.

Tabel 9. Parameter Hasil Interview

\begin{tabular}{|l|c|}
\hline \multicolumn{1}{|c|}{ Hasil Interview } & Nilai \\
\hline Gagal $(<55)$ & 1 \\
\hline Cukup (55-64) & 3 \\
\hline Memuaskan (65-79) & 4 \\
\hline Sangat memuaskan(80-100) & 5 \\
\hline
\end{tabular}

\subsection{Metode Analytic Hierarchy Process} (AHP)

Struktur AHP Calon Asisten Labor STMIK Indonesia Padang ditunjukkan pada Gambar 1.

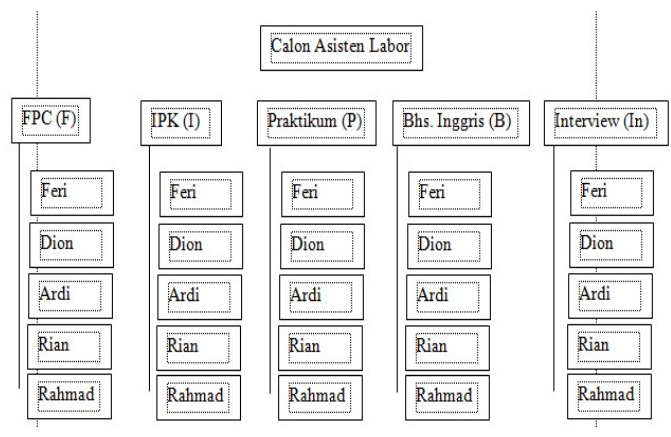

Gambar 1. Struktur AHP Calon Asisten Labor STMIK Indonesia Padang

\section{HASIL DAN PEMBAHASAN}

\subsection{Penerapan Perhitungan dengan}

Metode Simple Additive Weighting (SAW)

Berdasarkan Tabel 1 maka dibuat rating kecocokan kriteria berdasarkan parameter nilai setiap kriteria, ditunjukkan pada Tabel 10.

Tabel 10. Rating Kecocokan Kriteria

\begin{tabular}{|c|c|c|c|c|c|}
\hline Calon & \multicolumn{5}{|c|}{ Knitenia } \\
\cline { 2 - 6 } & FPC & IPK & Praktikum & B.nggnis & Interview \\
\hline Feri & 5 & 4 & 5 & 5 & 5 \\
\hline Dion & 5 & 2 & 4 & 5 & 5 \\
\hline Ardi & 1 & 5 & 3 & 5 & 1 \\
\hline Rian & 5 & 4 & 5 & 1 & 1 \\
\hline Rahmad & 1 & 2 & 3 & 5 & 5 \\
\hline
\end{tabular}

Langkah-langkah penyelesaian:

1) Vektor bobot :

$$
\mathrm{W}=[5,4,3,2,1]=\left[\begin{array}{l}
5 \\
4 \\
3 \\
2 \\
1
\end{array}\right]
$$

2) Matriks keputusan (X) berdasarkan kriteria,

$$
X=\left[\begin{array}{lllll}
5 & 4 & 5 & 5 & 5 \\
5 & 2 & 4 & 5 & 5 \\
1 & 5 & 3 & 5 & 1 \\
5 & 4 & 5 & 1 & 1 \\
1 & 2 & 3 & 5 & 5
\end{array}\right]
$$

3) Normalisasi matriks X berdasarkan persamaan $r_{i j}$ sehingga diperoleh matriks ternormalisasi R.

$$
R=\left[\begin{array}{ccccc}
1 & 0,8 & 1 & 1 & 1 \\
1 & 0,4 & 0,8 & 1 & 1 \\
0,2 & 1 & 0,6 & 1 & 0,2 \\
1 & 0,8 & 1 & 0,20,2 \\
0,2 & 0,4 & 0,6 & 1 & 1
\end{array}\right]
$$

Keterangan:

$r_{11}=1=$ nilai FPC Feri.

$r_{12}=0,8=$ nilai IPK Feri.

$r_{13}=1=$ nilai tes Praktikum Feri.

$r_{14}=1=$ nilai tes Bahasa Inggris Feri.

$r_{15}=1=$ nilai hasil Interview Feri.

$r_{\mathbf{2 1}}=1=$ nilai FPC Dion

$r_{22}=0,4=$ nilai IPK Dion.

$r_{23}=0,8=$ nilai tes Praktikum Dion.

$r_{24}=1=$ nilai tes Bahasa Inggris Dion. 
Penerapan Multimetode Berbasis Matriks Pada Seleksi Penerimaan Calon Asisten

Labor

Rahimullaily, Lakry Maltaf

$r_{25}=1=$ nilai hasil Interview Dion.

Laboratorium Komputer Program Studi

$r_{31}=0,2=$ nilai FPC Ardi

Sistem Informasi STMIK Indonesia Padang.

$r_{32}=1=$ nilai IPK Ardi

$r_{33}=0,6=$ nilai tes Praktikum Ardi.

$r_{34}=1=$ nilai tes Bahasa Inggris Ardi.

$r_{35}=0,2=$ nilai hasil Interview Ardi.

$r_{41}=1=$ nilai FPC Rian

Selanjutnya $V_{2}$ (Dion) dan $V_{4}$ (Rian) dapat dikategorikan dipertimbangkan untuk diterima sebagai asisten labor.

\subsection{Penerapan Perhitungan dengan Metode Analytic Hierarchy Process (AHP)}

$r_{42}=0,8=$ nilai IPK Rian

$r_{43}=1=$ nilai tes Praktikum Rian.

$r_{44}=0,2=$ nilai tes Bahasa Inggris Rian.

$r_{45}=0,2=$ nilai hasil Interview Rian.

$r_{51}=0,2=$ nilai FPC Rahmad.

$r_{52}=0,4=$ nilai IPK Rahmad.

$r_{53}=0,6=$ nilai tes Praktikum Rahmad.

$r_{\mathbf{5} 4}=1=$ nilai tes Bahasa Inggris Rahmad

$r_{55}=1=$ nilai hasil Interview Rahmad.

4) Dengan menggunakan rumus perkalian matriks maka diperoleh:

$\mathrm{V}=\mathrm{R}_{5 \times 5} \cdot \mathrm{W}_{5 \times 1}$

$$
\begin{aligned}
& \mathrm{V}=\left[\begin{array}{ccccc}
1 & 0,8 & 1 & 1 & 1 \\
1 & 0,4 & 0,8 & 1 & 1 \\
0,2 & 1 & 0,6 & 1 & 0,2 \\
1 & 0,8 & 1 & 0,20,2 \\
0,2 & 0,4 & 0,6 & 1 & 1
\end{array}\right] \cdot\left[\begin{array}{l}
5 \\
4 \\
3 \\
2 \\
1
\end{array}\right] \\
& \mathrm{V}=\left[\begin{array}{c}
14,2 \\
12 \\
9 \\
11,8 \\
7,4
\end{array}\right]=\left[\begin{array}{l}
V_{1} \\
V_{2} \\
V_{3} \\
V_{4} \\
V_{5}
\end{array}\right]
\end{aligned}
$$

$\mathrm{V}_{1}=14,2$ merupakan peringkat pertama

Kriteria FPC disimbolkan F, IPK disimbolkan I, tes praktikum disimbolkan P, tes Bahasa Inggris disimbolkan B, dan hasil interview disimbolkan In.

1) Perhitungan Untuk Semua Kriteria

a) Berdasarkan tingkat kepentingan yang sesuai dengan Tabel 3 maka dibentuk matriks perbandingan berpasangan untuk semua kriteria dan disederhanakan. Kedua matriks ditunjukkan pada Tabel 11 dan Tabel 12.

Tabel 11. Matriks Perbandingan Berpasangan Untuk Semua Kriteria

$\begin{array}{cccccc} & \text { F } & \text { I } & \text { P } & \text { B } & \text { In } \\ \text { F } & 1 & \frac{1}{3} & \frac{1}{5} & \frac{1}{3} & \frac{1}{7} \\ \text { I } & 3 & 1 & \frac{1}{5} & 1 & \frac{1}{7} \\ \text { P } & 5 & 5 & 1 & 3 & \frac{1}{3} \\ \text { B } & 3 & 1 & \frac{1}{3} & 1 & \frac{1}{5} \\ \text { In } & 7 & 7 & 3 & 5 & 1\end{array}$

karena memiliki nilai yang lebih besar dari yang lain. $\mathrm{V}_{1}$ merupakan nilai preferensi dari $\mathrm{A}_{1}$ dan $\mathrm{V}_{1}>13$ maka $\mathrm{A}_{1}$ atau dalam permasalahan ini adalah Feri yang dinilai layak diterima sebagai asisten labor di 


\begin{tabular}{lccccc} 
Tabel 12. Matriks Perbandingan \\
\multicolumn{5}{c}{ Berpasangan Untuk Semua } \\
Kriteria yang Disederhanakan \\
F & I & P & B & In \\
F & 1,00 & 0,33 & 0,2 & 0,33 & 0,1 \\
& & & 0 & & 4 \\
I & 3,00 & 1,00 & 0,2 & 1,00 & 0,1 \\
& & & 0 & & 4 \\
P & 5,00 & 5,00 & 1,0 & 3,00 & 0,3 \\
& & & 0 & & 3 \\
B & 3,00 & 1,00 & 0,3 & 1,00 & 0,2 \\
& & & 3 & & 0 \\
In & 7,00 & 7,00 & 3,0 & 5,00 & 1,0 \\
& 19,0 & 14,3 & 4,7 & 10,3 & 1,8 \\
Zkolom & 0 & 3 & 3 & 3 & 2
\end{tabular}

b) Untuk menormalkan data pada matriks perbandingan berpasangan yang disederhanakan maka dilakukan dengan cara membagi nilai setiap entri pada matriks tersebut dengan nilai total dari setiap kolom. Hasil matriks perbandingan yang dinormalkan ditunjukkan pada Tabel 13.

Tabel 13. Matriks Perbandingan Berpasangan Untuk Semua Kriteria yang Dinormalkan

$\begin{array}{cccccccc} & \text { F } & \text { I } & \text { P } & \text { B } & \text { In } & \Sigma \text { baris } & \lambda \\ \text { F } & 0,05 & 0,02 & 0,04 & 0,03 & 0,08 & 0,23 & 0,046 \\ \text { I } & 0,16 & 0,07 & 0,04 & 0,10 & 0,08 & 0,45 & 0,089 \\ \text { P } & 0,26 & 0,35 & 0,21 & 0,29 & 0,18 & 1,30 & 0,259 \\ \text { B } & 0,16 & 0,07 & 0,07 & 0,10 & 0,11 & 0,50 & 0,101 \\ \text { In } & 0,37 & 0,49 & 0,63 & 0,48 & 0,55 & 2,52 & 0,505\end{array}$

c) Menguji konsistensi semua kriteria. Nilai eigen maksimum diperoleh dengan menjumlahkan hasil perkalian jumlah kolom dengan eigen vektor.

$$
\begin{aligned}
\lambda_{\text {maksimum }} & =(19 \times 0,046)+(14,33 \times \\
0,089) & +(4,73 \times 0,259)+(10,33 \times \\
0,101) & +(1,82 \times 0,505)
\end{aligned}
$$

$=5,336$

$\mathrm{CI}=\frac{5,336-5}{4}=0,084$

Untuk $\mathrm{n}=5$ maka $\mathrm{IR}=1,12$, sehingga $\mathrm{CR}=\frac{0,084}{1,12}=0,075$. Karena $\mathrm{CR}<0,1$ maka kriteria konsisten. Berdasarkan Tabel 13 maka kriteria hasil interview merupakan kriteria yang paling penting dalam menentukan calon asisten labor dengan bobot 0,505 atau $50,5 \%$. Selanjutnya adalah tes praktikum dengan bobot 0,259 atau $25,9 \%$, tes Bahasa Inggris dengan bobot 0,101 atau $10,1 \%$, IPK dengan bobot 0,089 atau $8,9 \%$, dan FPC dengan bobot 0,046 atau $4,6 \%$.

d) Untuk memperoleh vektor prioritas semua kriteria, setiap unsur kriteria pada Tabel 12, di setiap barisnya dikalikan dan hasilnya ditarik akar pangkat 5. Selanjutnya hasil penarikan akar dibagi dengan jumlah kolom hasil penarikan akar. Hasil perhitungan ini dapat diperlihatkan pada kolom hasil penarikan akar dan vektor prioritas pada Tabel 14.

Tabel 14. Matriks Vektor Prioritas Semua Kriteria

\begin{tabular}{|c|c|c|c|c|c|c|c|c|}
\hline & & & & & & $\begin{array}{c}\text { Hasil } \\
\text { Penarikan }\end{array}$ & $\begin{array}{c}\text { Vektor } \\
\text { Prionitas }\end{array}$ \\
\hline F & 1,00 & 0,33 & 0,20 & 0,33 & 0,14 & 0,316 & 0,043 \\
\hline I & 3,00 & 1,00 & 0,20 & 1,00 & 0,14 & 0,612 & 0,084 \\
\hline P & 5,00 & 5,00 & 1,00 & 3,00 & 0,33 & 1,904 & 0,261 \\
\hline B & 3,00 & 1,00 & 0,33 & 1,00 & 0,20 & 0,725 & 0,099 \\
\hline In & 7,00 & 7,00 & 3,00 & 5,00 & 1,00 & 3,743 & 0,513 \\
\hline Kolom & 19,00 & 14,33 & 4,73 & 10,33 & 1,82 & 7,300 & \\
\hline L & & & & & & \\
\hline
\end{tabular}


2) Perhitungan Untuk Kriteria FPC

a) Matriks perbandingan berpasangan untuk kriteria FPC dan disederhanakan, ditunjukkan pada Tabel 15 dan Tabel 16.

Tabel 15. Matriks Perbandingan Berpasangan Untuk Kriteria FPC

Feri Dion Ardi Rian Rahmad

$\begin{array}{lccccc}\text { Feri } & 1 & 1 & 3 & 1 & 3 \\ \text { Dion } & 1 & 1 & 3 & 1 & 3 \\ \text { Ardi } & 1 / 3 & 1 / 3 & 1 & 1 / 3 & 1 \\ \text { Rian } & 1 & 1 & 3 & 1 & 3 \\ \text { Rahmad } & 1 / 3 & 1 / 3 & 1 & 1 / 3 & 1\end{array}$

Tabel 16. Matriks Perbandingan Berpasangan Untuk Kriteria FPC yang Disederhanakan

\begin{tabular}{|c|c|c|c|c|c|c|}
\hline & Feri & Dion & Ardi & Rian & Rahmad \\
\hline Feri & 1,00 & 1,00 & 3,00 & 1,00 & 3,00 \\
\hline Dion & 1,00 & 1,00 & 3,00 & 1,00 & 3,00 \\
\hline Ardi & 0,33 & 0,33 & 1,00 & 0,33 & 1,00 \\
\hline Rian & 1,00 & 1,00 & 3,00 & 1,00 & 3,00 \\
\hline Rahmad & 0,33 & 0,33 & 1,00 & 0,33 & 1,00 \\
\hline$\sum$ kolom & 3,67 & 3,67 & 11,00 & 3,67 & 11,00 \\
\hline
\end{tabular}

b) Menormalkan data kriteria FPC, ditunjukkan pada Tabel 17.

Tabel 17. Matriks Perbandingan Berpasangan Untuk Kriteria FPC yang Dinormalkan

\begin{tabular}{|l|c|c|c|c|c|c|c|}
\hline & Feri & Dion & Ardi & Rian & Rahmad & \multicolumn{1}{c|}{ baris } & $\lambda$ \\
\hline Feri & 0,27 & 0,27 & 0,27 & 0,27 & 0,27 & 1,36 & 0,27 \\
\hline Dion & 0,27 & 0,27 & 0,27 & 0,27 & 0,27 & 1,36 & 0,27 \\
\hline Ardi & 0,09 & 0,09 & 0,09 & 0,09 & 0,09 & 0,45 & 0,09 \\
\hline Rian & 0,27 & 0,27 & 0,27 & 0,27 & 0,27 & 1,36 & 0,27 \\
\hline Rahmad & 0,09 & 0,09 & 0,09 & 0,09 & 0,09 & 0,45 & 0,09 \\
\hline
\end{tabular}

c) Menguji Konsistensi Kriteria FPC

$\lambda_{\text {maksimum }}=(3,67 \times 0,27)+(3,67 \times$

$$
\begin{aligned}
& 0,27)+(11 \times 0,09)+(3,67 \\
& \times 0,27)+(11 \times 0,09)
\end{aligned}
$$

$$
=5
$$

$\mathrm{CI}=\frac{5-5}{4}=0$

Untuk $\mathrm{n}=5$ maka $\mathrm{IR}=1,12$, sehingga $\mathrm{CR}=\frac{0}{1_{1} 12}=0$. Karena $\mathrm{CR}$ $<0,1$ maka FPC konsisten. Berdasarkan Tabel 17 maka Feri, Dion, Rian merupakan calon asisten labor yang diprioritaskan dengan bobot 0,27 atau $27 \%$. Selanjutnya adalah Ardi dan Rahmad dengan bobot 0,09 atau $9 \%$.

d) Perhitungan total ranking/ prioritas untuk kriteria FPC yaitu dengan mengalikan vektor eigen $(\lambda)$ kriteria FPC dengan vektor prioritas kriteria FPC. Tabel 18 menunjukkan hasil perhitungan total ranking/ prioritas untuk kriteria FPC:

Tabel 18. Matriks Total Ranking (TR) Untuk Kriteria FPC

\begin{tabular}{|l|l|}
\hline TR Feri & $0,27 \times 0,043=0,012$ \\
\hline TR Dion & $0,27 \times 0,043=0,012$ \\
\hline TR Ardi & $0,09 \times 0,043=0,004$ \\
\hline TR Rian & $0,27 \times 0,043=0,012$ \\
\hline TR Rahmad & $0,09 \times 0,043=0,004$ \\
\hline
\end{tabular}

Berdasarkan Tabel 18 diketahui urutan prioritas calon asisten labor dari kriteria FPC adalah:

1. Feri, Dion, Rian

2. Ardi, Rahmad

3) Perhitungan Untuk Kriteria IPK

a) Matriks perbandingan berpasangan untuk kriteria IPK dan disederhanakan ditunjukkan pada Tabel 19 dan Tabel 20.

Tabel 19. Matriks Perbandingan 
Jurnal Derivat Volume 4 No. 1 juli 2017 (ISSN: 2407 - 3792)

Halaman $37-51$

\begin{tabular}{lccccc}
\hline \multicolumn{7}{c}{ Berpasangan Untuk Kriteria } \\
& IPK & & & & \\
& Feri & Dion & Ardi & Rian & Rahmad \\
Feri & 1 & 3 & $1 / 3$ & 1 & 3 \\
Dion & $1 / 3$ & 1 & $1 / 5$ & $1 / 3$ & 1 \\
Ardi & 3 & 5 & 1 & 3 & 5 \\
Rian & 1 & 3 & $1 / 3$ & 1 & 3 \\
Rahmad & $1 / 3$ & 1 & $1 / 5$ & $1 / 3$ & 1
\end{tabular}

Tabel 20. Matriks Perbandingan

Berpasangan Untuk Kriteria

IPK yang Disederhanakan

$\begin{array}{lccccc} & \text { Feri } & \text { Dion } & \text { Ardi } & \text { Rian } & \text { Rahmad } \\ \text { Feri } & 1,000 & 3,000 & 0,333 & 1,000 & 3,000 \\ \text { Dion } & 0,333 & 1,000 & 0,200 & 0,333 & 1,000 \\ \text { Ardi } & 3,000 & 5,000 & 1,000 & 3,000 & 5,000 \\ \text { Rian } & 1,000 & 3,000 & 0,333 & 1,000 & 3,000 \\ \text { Rahmad } & 0,333 & 1,000 & 0,200 & 0,333 & 1,000 \\ \sum_{\text {kolom }} & 5,67 & 13,00 & 2,07 & 5,67 & 13,00\end{array}$

b) Menormalkan data kriteria IPK ditunjukkan pada Tabel 21.

Tabel 21. Matriks Perbandingan Berpasangan Untuk Kriteria IPK yang Dinormalkan

\begin{tabular}{|l|r|r|r|r|r|r|r|} 
& Feri & Dion & Ardi & Rian & Rahmad & Laris & $\lambda$ \\
\hline Feri & 0,18 & 0,23 & 0,16 & 0,18 & 0,23 & 0,98 & 0,20 \\
\hline Dion & 0,06 & 0,08 & 0,10 & 0,06 & 0,08 & 0,37 & 0,07 \\
\hline Ardi & 0,53 & 0,38 & 0,48 & 0,53 & 0,38 & 2,31 & 0,46 \\
\hline Rian & 0,18 & 0,23 & 0,16 & 0,18 & 0,23 & 0,98 & 0,20 \\
\hline Rahmad & 0,06 & 0,08 & 0,10 & 0,06 & 0,08 & 0,37 & 0,07 \\
\hline
\end{tabular}

c) Menguji konsistensi kriteria IPK.

$$
\begin{aligned}
& \lambda_{\text {maksimum }}=(5,67 \times 0,2)+(13 \times \\
&0,07)+(2,07 \times 0,46)+ \\
&(5,67 \times 0,20)+(13 \times \\
&0,07) \\
&=5,082 \\
& C I=\frac{5,082-\mathbf{5}}{4}=0,021
\end{aligned}
$$

Untuk $\mathrm{n}=5$ maka $\mathrm{IR}=1,12$, sehingga $C R=\frac{0,021}{1,12}=0.018$. Karena CR $<0,1$ maka IPK konsisten. Berdasarkan Tabel 21 maka Ardi merupakan calon asisten labor yang diprioritaskan dengan bobot 0,46 atau 46\%. Selanjutnya adalah Feri dan Rian dengan bobot 0,20 atau 20\%. Selanjutnya adalah Dion dan Rahmad dengan bobot 0,07 atau $7 \%$.

d) Perhitungan total ranking/ prioritas untuk kriteria IPK ditunjukkan pada Tabel 22.

Tabel 22. Matriks Total Ranking (TR) Untuk Kriteria IPK

\begin{tabular}{|l|l|}
\hline TR Feri & $0,20 \times 0,084=0,0164$ \\
\hline TR Dion & $0,07 \times 0,084=0,0062$ \\
\hline TR Ardi & $0,46 \times 0,084=0,0388$ \\
\hline TR Rian & $0,20 \times 0,084=0,0164$ \\
\hline TR Rahmad & $0,07 \times 0,084=0,0062$ \\
\hline
\end{tabular}

Berdasarkan Tabel 22 diketahui bahwa urutan prioritas calon asisten labor dari kriteria IPK adalah:

1. Ardi

2. Feri, Rian

3. Dion, Rahmad

4) Perhitungan Untuk Kriteria Tes Praktikum

a) Matriks perbandingan berpasangan untuk kriteria tes praktikum dan disederhanakan ditunjukkan pada Tabel 23 dan Tabel 24. 
Penerapan Multimetode Berbasis Matriks Pada Seleksi Penerimaan Calon Asisten

Labor

Rahimullaily, Lakry Maltaf

Tabel 23. Matriks Perbandingan

Berpasangan Untuk Kriteria

Tes Praktikum

Feri Dion Ardi Rian Rahmad

$\begin{array}{llllll}\text { Feri } & 1 & 3 & 5 & 1 & 5\end{array}$

Dion $1 / 3 \quad 1 \quad 3 \quad 1 / 3 \quad 3$

Ardi $\quad 1 / 5 \quad 1 / 3 \quad 1 \quad 1 / 5 \quad 1$

$\begin{array}{llllll}\text { Rian } & 1 & 3 & 5 & 1 & 5\end{array}$

Rahmad $1 / 5 \quad 1 / 3 \quad 1 \quad 1 / 5 \quad 1$

Tabel 24. Matriks Perbandingan Berpasangan Untuk Kriteria Tes Praktikum yang

Disederhanakan

$\begin{array}{cccccc} & \text { Feri } & \text { Dion } & \text { Ardi } & \text { Rian } & \text { Rahmad } \\ \text { Feri } & 1,000 & 3,000 & 5,000 & 1,000 & 5,000 \\ \text { Dion } & 0,333 & 1,000 & 3,000 & 0,333 & 3,000 \\ \text { Ardi } & 0,200 & 0,333 & 1,000 & 0,200 & 1,000 \\ \text { Rian } & 1,000 & 3,000 & 5,000 & 1,000 & 5,000 \\ \text { Rahmad } & 0,200 & 0,333 & 1,000 & 0,200 & 1,000 \\ \sum_{\text {kolom }} & 2,733 & 7,667 & 15,000 & 2,733 & 15,000\end{array}$

b) Menormalkan data kriteria tes praktikum, ditunjukkan pada Tabel 25.

Tabel 25. Matriks Perbandingan

Berpasangan Untuk Kriteria Tes Praktikum yang Dinormalkan

\begin{tabular}{|l|c|c|c|c|c|c|c|}
\hline & Feri & Dion & Ardi & Rian & Rahmad & Laris & $\lambda$ \\
\hline Feri & 0,366 & 0,391 & 0,333 & 0,366 & 0,333 & 1,790 & 0,358 \\
\hline Dion & 0,122 & 0,130 & 0,200 & 0,122 & 0,200 & 0,774 & 0,155 \\
\hline Ardi & 0,073 & 0,043 & 0,067 & 0,073 & 0,067 & 0,323 & 0,065 \\
\hline Rian & 0,366 & 0,391 & 0,333 & 0,366 & 0,333 & 1,790 & 0,358 \\
\hline Rahmad & 0,073 & 0,043 & 0,067 & 0,073 & 0,067 & 0,323 & 0,065 \\
\hline
\end{tabular}

c) Menguji konsistensi kriteria tes praktikum

$$
\begin{aligned}
& \lambda_{\text {maksimum }}=(2,733 \times 0,358)+ \\
&(7,667 \times 0,155)+(15 \times \\
&0,065)+(2,733 \times \\
&0,358)+(15 \times 0,065) \\
&= 5,083 \\
& \mathrm{CI}=\frac{5,082-5}{4}=0,021
\end{aligned}
$$

Untuk $\mathrm{n}=5$ maka $\mathrm{IR}=1,12$, sehingga $\mathrm{CR}=\frac{0,021}{1,12}=0.018$.

Karena $\mathrm{CR}<0,1$ maka tes praktikum konsisten. Berdasarkan Tabel 25 maka Feri dan Rian merupakan calon asisten labor yang diprioritaskan dengan bobot 0,358 atau $35,8 \%$. Selanjutnya adalah Dion dengan bobot 0,155 atau $15,5 \%$. Selanjutnya adalah Ardi dan Rahmad dengan bobot 0,065 atau $6,5 \%$.

d) Perhitungan total ranking/ prioritas untuk kriteria tes praktikum, ditunjukkan pada Tabel 26.

Tabel 26. Matriks Total Ranking (TR) Untuk Kriteria Tes Praktikum

\begin{tabular}{|l|l|}
\hline TR Feri & $0,358 \times 0,261=0,0933$ \\
\hline TR Dion & $0,155 \times 0,261=0,0404$ \\
\hline TR Ardi & $0,065 \times 0,261=0,0169$ \\
\hline TR Rian & $0,358 \times 0,261=0,0933$ \\
\hline TR Rahmad & $0,065 \times 0,261=0,0169$ \\
\hline
\end{tabular}

Berdasarkan Tabel 26 diketahui bahwa urutan prioritas calon asisten labor berdasarkan kriteria tes praktikum adalah:

1. Feri, Rian

2. Dion

3. Ardi, Rahmad

5) Perhitungan Untuk Kriteria Tes Bahasa Inggris

a) Matriks perbandingan berpasangan untuk kriteria tes Bahasa Inggris dan disederhanakan, ditunjukkan pada Tabel 27 dan Tabel 28. 
Tabel 27. Matriks Perbandingan Berpasangan Untuk Kriteria Tes Bahasa Inggris

$\begin{array}{lccccc} & \text { Feri } & \text { Dion } & \text { Ardi } & \text { Rian } & \text { Rahmad } \\ \text { Feri } & 1 & 1 & 1 & 7 & 1 \\ \text { Dion } & 1 & 1 & 1 & 7 & 1 \\ \text { Ardi } & 1 & 1 & 1 & 7 & 1 \\ \text { Rian } & 1 / 7 & 1 / 7 & 1 / 7 & 1 & 1 / 7 \\ \text { Rahmad } & 1 & 1 & 1 & 7 & 1\end{array}$

Tabel 28. Matriks Perbandingan

Berpasangan Untuk Kriteria Tes

Bahasa Inggris yang

Disederhanakan

$\begin{array}{lccccc} & \text { Feri } & \text { Dion } & \text { Ardi } & \text { Rian } & \text { Rahmad } \\ \text { Feri } & 1,000 & 1,000 & 1,000 & 7,000 & 1,000 \\ \text { Dion } & 1,000 & 1,000 & 1,000 & 7,000 & 1,000 \\ \text { Ardi } & 1,000 & 1,000 & 1,000 & 7,000 & 1,000 \\ \text { Rian } & 0,143 & 0,143 & 0,143 & 1,000 & 0,143 \\ \text { Rahmad } & 1,000 & 1,000 & 1,000 & 7,000 & 1,000 \\ \text { ¿kolom } & 4,143 & 4,143 & 4,143 & 29,000 & 4,143\end{array}$

b) Menormalkan data kriteria tes Bahasa Inggris ditunjukkan pada Tabel 29.

Tabel 29. Matriks Perbandingan Berpasangan Untuk Kriteria Tes Bahasa Inggris yang Dinormalkan

\begin{tabular}{|l|c|c|c|c|c|c|c|} 
& Feri & Dion & Ardi & Rian & Rahmad & baris & $\lambda$ \\
\hline Feri & 0,241 & 0,241 & 0,241 & 0,241 & 0,241 & 1,207 & 0,241 \\
\hline Dion & 0,241 & 0,241 & 0,241 & 0,241 & 0,241 & 1,207 & 0,241 \\
\hline Ardi & 0,241 & 0,241 & 0,241 & 0,241 & 0,241 & 1,207 & 0,241 \\
\hline Rian & 0,034 & 0,034 & 0,034 & 0,034 & 0,034 & 0,172 & 0,034 \\
\hline Rahmad & 0,241 & 0,241 & 0,241 & 0,241 & 0,241 & 1,207 & 0,241 \\
\hline
\end{tabular}

c) Menguji konsistensi kriteria tes Bahasa Inggris

$$
\begin{aligned}
\lambda_{\text {maksimum }}= & (4,143 \times 0,241)+ \\
& (4,143 \times 0,241)+ \\
& (4,143 \times 0,241)+(29 \times \\
& 0,241)+(4,143 \times \\
& 0,241) \\
= & 5
\end{aligned}
$$

$$
\mathrm{CI}=\frac{5-5}{4}=0
$$

Untuk $\mathrm{n}=5$ maka $\mathrm{IR}=1,12$, sehingga $\mathrm{CR}=\frac{0}{1,12}=0$. Karena $\mathrm{CR}$ $<0,1$ maka tes Bahasa Inggris konsisten. Berdasarkan Tabel 29 maka Feri, Dion, Ardi, Rahmad merupakan calon asisten labor yang diprioritaskan dengan bobot 0,241 atau $24,1 \%$. Selanjutnya adalah Rian dengan bobot 0,034 atau $3,4 \%$.

d) Perhitungan total ranking/ prioritas untuk kriteria tes Bahasa Inggris ditunjukkan pada Tabel 30.

Tabel 30. Matriks Total Ranking (TR) Untuk Kriteria Tes Bahasa Inggris

\begin{tabular}{|l|r|}
\hline TR Feri & 0,024 \\
\hline TR Dion & 0,024 \\
\hline TR Ardi & 0,024 \\
\hline TR Rian & 0,003 \\
\hline TR Rahmad & 0,024 \\
\hline
\end{tabular}

Berdasarkan Tabel 30 diketahui bahwa urutan prioritas calon asisten labor berdasarkan kriteria tes Bahasa Inggris adalah:

1. Feri, Dion, Ardi, Rahmad

2. Rian

6) Perhitungan Untuk Kriteria Hasil Interview

a) Matriks perbandingan berpasangan untuk kriteria hasil interview dan disederhanakan, ditunjukkan pada Tabel 31 dan Tabel 32. 
Penerapan Multimetode Berbasis Matriks Pada Seleksi Penerimaan Calon Asisten

Labor

Rahimullaily, Lakry Maltaf

Tabel 31. Matriks Perbandingan Berpasangan Untuk Kriteria Hasil Interview

Feri Dion Ardi Rian Rahmad

$\begin{array}{llllll}\text { Feri } & 1 & 1 & 7 & 7 & 1 \\ \text { Dion } & 1 & 1 & 7 & 7 & 1 \\ \text { Ardi } & 1 / 7 & 1 / 7 & 1 & 1 & 1 / 7 \\ \text { Rian } & 1 / 7 & 1 / 7 & 1 & 1 & 1 / 7 \\ \text { Rahmad } & 1 & 1 & 7 & 7 & 1\end{array}$

Tabel 32. Matriks Perbandingan Berpasangan Untuk Kriteria Hasil Interview yang

Disederhanakan

\begin{tabular}{|c|c|c|c|c|c|c|}
\hline & Feri & Dion & Ardi & Rian & Rahmad \\
\hline Feri & 1,000 & 1,000 & 7,000 & 7,000 & 1,000 \\
\hline Dion & 1,000 & 1,000 & 7,000 & 7,000 & 1,000 \\
\hline Ardi & 0,143 & 0,143 & 1,000 & 1,000 & 0,143 \\
\hline Rian & 0,143 & 0,143 & 1,000 & 1,000 & 0,143 \\
\hline Rahmad & 1,000 & 1,000 & 7,000 & 7,000 & 1,000 \\
\hline$\sum_{\text {k kolom }}$ & 3,286 & 3,286 & 23,000 & 23,000 & 3,286 \\
\hline
\end{tabular}

b) Menormalkan data kriteria hasil interview ditunjukkan pada Tabel 33.

Tabel 33. Matriks Perbandingan Berpasangan Untuk Kriteria Hasil Interview yang Dinormalkan

\begin{tabular}{|l|c|c|c|c|c|c|c|}
\hline & Feri & Dion & Ardi & Rian & Rahmad & $\sum_{\text {baris }}$ & $\lambda$ \\
\hline Feni & 0,304 & 0,304 & 0,304 & 0,304 & 0,304 & 1,522 & 0,304 \\
\hline Dion & 0,304 & 0,304 & 0,304 & 0,304 & 0,304 & 1,522 & 0,304 \\
\hline Ardi & 0,043 & 0,043 & 0,043 & 0,043 & 0,043 & 0,217 & 0,043 \\
\hline Rian & 0,043 & 0,043 & 0,043 & 0,043 & 0,043 & 0,217 & 0,043 \\
\hline Rahmad & 0,304 & 0,304 & 0,304 & 0,304 & 0,304 & 1,522 & 0,304 \\
\hline
\end{tabular}

c) Menguji konsistensi kriteria hasil interview

$$
\begin{aligned}
\lambda_{\text {maksimum }}= & (3,286 \times 0,304)+ \\
& (3,286 \times 0,304)+(23 \times \\
& 0,043)+(23 \times 0,43)+ \\
& (3,286 \times 0,304) \\
= & 5 \\
C I=\frac{s-s}{4}= & 0
\end{aligned}
$$

Untuk $\mathrm{n}=5$ maka $\mathrm{IR}=1,12$, sehingga $\mathrm{CR}=\frac{\mathrm{O}}{1,12}=0$. Karena $\mathrm{CR}$

$<0,1$ maka Interview konsisten.

Berdasarkan Tabel 33 maka Feri, Dion, Rahmad merupakan calon asisten labor yang diprioritaskan dengan bobot 0,304 atau 30,4\%. Selanjutnya adalah Ardi, Rian dengan bobot 0,043 atau 4,3\%.

d) Perhitungan total ranking/ prioritas untuk kriteria hasil interview ditunjukkan pada Tabel 34.

Tabel 34. Matriks Total Ranking (TR) Untuk Kriteria Hasil Interview

\begin{tabular}{|l|r|}
\hline TR Feri & 0,156 \\
\hline TR Dion & 0,156 \\
\hline TR Ardi & 0,022 \\
\hline TR Rian & 0,022 \\
\hline TR Rahmad & 0,156 \\
\hline
\end{tabular}

Berdasarkan Tabel 34 diketahui bahwa urutan prioritas calon asisten labor adalah:

1. Feri, Dion, Rahmad

2. Ardi, Rian

7) Perhitungan Total Ranking untuk Semua

\begin{tabular}{|c|c|c|c|c|c|c|}
\hline & FPC & IPK & Praktikum & $\begin{array}{l}\text { Bahasa } \\
\text { Inggnis }\end{array}$ & Interview & Jumlah \\
\hline Fen & 0,0118 & 0,0164 & 0,0933 & 0,0240 & 0,1561 & 0,3016 \\
\hline Dion & 0,0118 & 0,0062 & 0,0404 & 0,0240 & 0,1561 & 0,2385 \\
\hline Ardi & 0,0039 & 0,0388 & 0,0169 & 0,0240 & 0,0223 & 0,1059 \\
\hline Rian & 0,0118 & 0,0164 & 0,0933 & 0,0034 & 0,0223 & 0,1472 \\
\hline Rahmad & 0,0039 & 0,0062 & 0,0169 & 0,0240 & 0,1561 & 0,2071 \\
\hline
\end{tabular}
Kriteria

Perhitungan total ranking untuk semua kriteria ditunjukkan pada Tabel 35.

Tabel 35. Matriks Total Ranking Untuk Semua Kriteria 
Berdasarkan Tabel 34, maka Feri dinyatakan urutan pertama untuk diterima sebagai asisten labor di Laboratorium Komputer Program Studi Sistem Informasi STMIK Indonesia.

\section{KESIMPULAN}

Kesimpulan yang diperoleh dalam penelitian ini:

a. Dengan menerapkan metode SAW dan AHP maka pengambilan keputusan oleh Kepala Laboratorium Komputer Program Studi Sistem Informasi STMIK Indonesia Padang lebih punya dasar keputusan dalam menentukan asisten labor STMIK Indonesia Padang karena setiap kriteria mendapatkan penilaian.

1) Dengan metode SAW diperoleh juga hasil, jika ingin memilih asisten labor lebih dari satu orang, maka memungkinkan Kepala Labor untuk memilih calon asisten yang mendapat kategori "dapat dipertimbangkan".

2) Dengan metode AHP diperoleh juga hasil Total Ranking masing-masing kriteria untuk setiap calon asisten labor, sehingga memungkinkan Kepala Laboratorium untuk mempertimbangkan penerimaan asisten labor lebih dari satu orang. b. Perhitungan dengan banyak kriteria (Formulir Pengajuan Calon, IPK, tes praktikum, tes Bahasa Inggris, dan hasil interview) baik dengan menggunakan metode SAW maupun dengan metode AHP diperoleh bahwa Feri merupakan calon asisten labor yang layak diterima sebagai asisten labor di Laboratorium Komputer Program Studi Sistem Informasi STMIK Indonesia Padang.

\section{REFERENSI}

Darmanto, Eko, et al., 2014. Penerapan Metode AHP (Analythic Hierarchy Process) Untuk Menentukan Kualitas Gula Tebu. Jurnal SIMETRIS, Vol 5 No 1 April 2014. ISSN: 2252-4983.

Dokumen Laboratorium Komputer Program Studi Sistem Informasi STMIK Indonesia, 2016.

Jacob, Bill. 1990. Linear Algebra. New York: W. H. Freeman and Company.

Kusrini. 2007. Konsep dan Aplikasi Sistem Pendukung Keputusan. Yogyakarta: Penerbit Andi Offset.

Nofriansyah, Dicky. 2014. Konsep Data Mining Sistem Pendukung Keputusan. Yogyakarta: Penerbit CV. Budi Utama. 